\title{
MODUSI ESTETSKE OBRADE, PERFEKCIONIZAM I DIVLJENJE KAO PREDIKTORI UMETNIČKE VREDNOSTI ${ }^{2}$
}

\begin{abstract}
Apstrakt
Cilj istraživanja bio je ispitati da li se percipirana umetnička vrednost kompozicija može predvideti perfekcionizmom i divljenjem, kao i modusima esteste obrade $(\mathrm{H}-$ harmonija i R - redundantnost). Uzorak je prigodan i čini ga 92 ispitanika $\left(N_{\mathrm{M}}=10\right.$, $\left.N_{\check{Z}}=82\right)$, prosečne starosti 24.65 godina $(S D=6.89)$. Korišćeni su sledeći instrumenti: Skala pozitivnog i negativnog perfekcionizma, Skala divljenja i skale semantičkog diferencijala, koje su korišćene za procenu sklada i redundantnosti, kao i percipirane umetničke vrednosti. Stimuluse su činile kompozicije iz devet umetničkih pravaca: renesanse, romantizma, impresionizma, ekspresionizma, postimpresionizma, fovizma, kubizma, apstraktne umetnosti i nadrealizma. Za svaki od ovih pravaca su izabrane tri slike jednog najistaknutijeg predstavnika (izostavljajući najpoznatije komade), da bi kvalitet umetničkih dela bio ujednačen. Za analizu podataka korišćena je hijerarhijska linearna regresija. Prediktori u prvom koraku bili su modusi estetske obrade, perfekcionizam je dodat u drugom, a subskale divljenja dodate su u trećem koraku. Kriterijum je umetnička vrednost. Model sačinjen od H i R objašnjava $26 \%$ ukupne varijanse umetničke vrednosti $(p<.01)$. Subskale perfekcionizma i divljenja ne daju značajan doprinos predikciji. Statistički značajan pojedinačni prediktor je $\mathrm{R}$, redundantnost $(\beta$ $=.39, t=2.59, p=.01)$. Ispitano je i potencijalno postojanje medijacije, međutim, rezultati analize ukazuju na to da ne postoji statistički značajan medijatorski efekat.
\end{abstract}

Ključne reči: perfekcionizam, divljenje, modusi estetske obrade, Harmonija, Redundantnost, umetnička vrednost

Dosadašnja istraživanja su pokazala da osobe sklone perfekcionizmu generalno preferiraju jednostavnija dela (Basak, 2012). Sa druge strane, divljenje predstavlja jednu od centralnih estetskih emocija (Konečni, 2005), ali kako su se ovi radovi više bavili preferencijama nego procenom umetničke vrednosti, u ovom radu kao kriterijumska varijabla uključena je upravo umetnička vrednost. Kao dodatak korišćeni su i modusi estetske preferencije (H i R). D nivo podrazumeva treći nivo modusa estetske obrade, koji predstavlja originalna umetnička dela (Ognjenović, 2003).

\footnotetext{
${ }^{1}$ miljananikolic977@gmail.com

${ }^{2}$ Deo rezultata je prezentovan na XVI konferenciji Dani primenjene psihologije i objavljen u vidu rezimea. Citirati rad na sledeći način: Nikolić, M. (2021). Modusi estetske obrade, perfekcionizam i divljenje kao prediktori umetničke vrednosti. Godišnjak za psihologiju, 18, 107-122. https://doi.org/10.46630/ gpsi.18.2021.07
} 
Budući da on, po teoriji estetskih modusa (Ognjenović, 2003), uključuje umetničku vrednost odnosno bezvrednost, neće biti razmatran u ovom istraživanju.

Dakle, cilj ovog istraživanja je utvrditi da li su modusi estetske obrade (H i R), perfekcionizam i divljenje, statistički značajni prediktori umetničke vrednosti.

\section{Perfekcionizam}

Definicije perfekcionizma su usredsređene na njegovo opisivanje kao dostizanje visokih standarda i postojanje samokritičnosti zbog neispunjavanja istih (Limburg et al., 017). Treba razlikovati pozitivan i negativan perfekcionizam (Terry-Short et al., 1995). Teri Šort i saradnici (Terry-Short et al., 1995) su u svom članku o pozitivnom i negativnom perfekcionizmu predstavili potencijalnu teorijsku osnovu koja treba da objasni razliku uzmeđu ova dva tipa perfekcionizma. Ona se bazira na učenju Skinera (Skiner, 1969) i tradicionalnom bihejviorističkom učenju o posledicama. Teri Šort i saradnici (Terry-Short et al, 1995) su predložili da se pozitivni perfekcionizam poveže sa pozitivnim potkrepljenjem, a negativni sa negativnim. Skiner (Skiner, 1969) je smatrao da ako osoba uradi nešto što je posledica niza pozitivnih potkrepljenja u prošlosti, onda se ta aktivnost smatra onom koja je nastala slobodnim izborom, sa druge strane, ako je učinjena da bi se izbegla negativna posledica onda se smatra prisilnom aktivnošću. Slejd i Ovens (Slade \& Owens, 1998) navode da se pozitivni perfekcionizam odnosi na ponašanje i aktivnosti koje su usmerene ka visokim ciljevima i obezbeđivanju pozitivnih posledica. Negativni perfekcionizam se takođe odnosi na aktivnosti koje su usmerene ka postizanju određenih ciljeva, ali da bi se izbegle negativne posledice. Dakle, dok pozitivni perfekcionizam pokreće želja za uspehom, savršenstvom, negativni se bazira na strahu od neuspeha i begu od nesavršenstava. Ponašanje karakteristično za pozitivni perfekcionizam je pristupajuće ponašanje, dok negativni karakteriše izbegavajuće. U socijalnom domenu pozitivni perfekcionisti će težiti da dobiju odobravanje, dok će osobe sa negativnim perfekcionizmom biti sklone izbegavanju neodobravanja. Manifestno ponašanje i jednog i drugog oblika perfekcionizma može biti identično, ali su ciljevi koji ih pokreću različiti (Slade \& Owens, 1998). Slejd i Ovens takođe navode da su pomenuti oblici perfekcionizma povezani sa self konceptom. Osoba sa pozitivnim perfekcionizmom teži da se približi svom idealnom selfu, dok su oni sa negativnim perfekcionizmom motivisani željom da se udalje od selfa koji ih plaši (Slade \& Owens, 1998). Bazak (Basak, 2012) navodi da perfekcioniste odlikuju osobine poput teškoće samoizražavanja i nefleksibilno crtanje, odnosno takve njegove karakteristike. Ovakav vid crtanja se znatno razlikuje od istraživačkog, fleksibilnog, koje se odlikuje velikim brojem nasumičnih linija i pokušajima i pogreškama, da bi se pronašao najadekvatniji način predstavljanja teme. Takođe, perfekcionisti najčešće pri odabiru preferiraju precizne crteže koje karakteriše simetrija (Basak, 2012).

\section{Divljenje}

Keltner i Hait (Keltner \& Haidt, 2003) divljenje opisuju kao susret sa perceptivno ogromnim stimulusom koji osobu primorava na prilagođavanje. Divljenje se može osećati prema različitim pojavama. Često se javlja upravo u umetnosti, a prisutno je i u ostalim domenima našeg života, poput religioznosti (Keltner \& Haidt, 
2003). Učestalije ga izazivaju stimulusi koji su bogati informacijama, nego prilika za društveni angažman i nagradu koja je materijalna (Shiota et al., 2007). Interpesonalno divljenje je jedinstveni kvalitet iskustva divljenja koje je manje intenzivno od divljenja koje izaziva priroda (Graziosi \& Yaden, 2019). Dok divljenje usmereno ka prirodi uključuje osećaj opšte povezanosti sa prirodom i izmenjenu percepciju vremena, te komponetne izostaju kada je u pitanju interpersonalno divljenje (Graziosi \& Yaden, 2019). Divljenje izaziva osećaj poniznosti u susretu sa pojavom (Stellar et al., 2018). U psihologiji nije u većoj meri zastupljeno bavljenje konstruktom divljenja, a razlog tome, po Keltneru (Keltner \& Haidt, 2003), mogao bi biti to što nije identifikovana posebna facijalna ekspresija koja mu pripada, a koja bi divljenje razlikovala od, na primer, iznenađenja. Konečni (2005) estetsko divljenje posmatra kao reakciju na uzvišeni sadržaj, onaj koji krasi lepota ili retkost. Takođe navodi da ono biva propraćeno drhtavicom i uzbuđenjem (Konečni, 2005). Osobe koje osećaju divljenje su manje nestrpljive i sa osećajem da imaju više vremena koje mogu iskoristiti, sa većom spremnošću za pružanje pomoći, većim zadovoljstvom životom, usmerenije su na iskustvo, a ne na materijalni aspekt u životu (Rudd et al., 2012). Osećaj divljenja povećava verovatnoću da osoba ispolji prosocijalno ponašanje (Piff et al., 2015). Osobe koje su sklonije divljenju se procenjuju kao skromnije (Stellar et al., 2018) i imaju veću šansu za reviziju mentalnih predstava koje imaju o svetu (Shiota et al., 2007).

\section{Kognitivna teorija estetskog odlučivanja}

Za nastanak savremene teorije estetskog odlučivanja odgovorni su istraživači u Laboratoriji za eksperimentalnu psihologiju pri Filozofskom fakultetu u Beogradu (Ognjenović, 2003). Naime, tamošnja istraživanja su pokazala da sa promenom vremena koje je potrebno da bi se doneo estetski sud, dolazi do promene preferencija ispitanika. Putem istraživanja dobijena su tri nivoa obrade stimulusa, H, R i D nivo. H nivo se zasniva na harmoniji tj. simetriji. $\mathrm{R}$ nivo se temelji na redundansi, odnosno, na bogatsvu detalja. D nivo čine crteži koji nisu modifikovani da bi odgovarali nekom od prethodna dva nivoa, dakle to su bili originalni crteži i za njih je bilo potrebno najviše vremena da bi bili obrađeni tj. potrebna je dublja kognitivna obrada informacija kada je ovaj nivo u pitanju. Oznaka D se odnosi na distancu. Istraživanja su pokazala da pri najkraćem vremenskom izlaganju odabir slika ide u korist H nivoa, dok se sa produžavanjem vremena ekspozicije preferencije menjaju, pa se kod malo dužeg izlaganja bira R nivo, a kod najdužeg D. Samim tim se pokazalo da je različita dubina obrade stimulusa sa različitih nivoa. Prefencije predstavljaju razvojni fenomen (Ognjenović, 2003). Mlađa deca, starosti do šest godina, preferiraju stimuluse sa $\mathrm{H}$ nivoa, sa deset godina biraju kompozicije koje su ukrašene, dakle sa $\mathrm{R}$ nivoa, a sa šesnaest dominantno biraju one koje pripadaju D nivou. Ognjenović (2003) takođe navodi da osobe manjeg obrazovanja češće biraju stimuluse sa R nivoa ili pak H, i kada nemaju ograničeno vreme za odabir istih. On sa saradnikom (Ognjenović i Morača, 1994) sprovodi jedno istraživanje koje se tiče modusa estetske obrade i upoređuje studente psihologije i one koje studiraju na Fakultetu dramskih umetnosti. 
Zadatak studenata je bio da procene umetničku vrednost stimulusa sa H, R i D nivoa. Kao stimulusi sa najvećom vrednošću ocenjeni su oni sa $\mathrm{D}$ nivoa, potom sledi $\mathrm{R}$ pa $\mathrm{H}$ nivo, pritom nisu otkrivene razlike između grupa. Sa druge strane, pokazalo se da studenti psihologije, kada biraju stimuluse koji su lepi, biraju one sa R nivoa, dok studenti koji se bave umetnošću tj. umetnički su obrazovani, dosledno biraju one sa D nivoa (Ognjenović i Morača, 1994).

\section{Metod}

\section{Uzorak i procedura}

Uzorak je prigodan i sačinjavaju ga 92 ispitanika (89.1\% žena), uzrasta od 19 do 56 godina $(A S=24.65, S D=6.89)$.

Istraživanje je sprovedeno online, putem google upitnika. Google upitnici su deljeni putem Facebook-a. Istraživanje je sprovedeno tako što su ispitanici najpre popunjavali upitnik perfekcionizma, potom skalu divljenja, a na kraju su ocenjivali svaki stimulus zasebno, na listi stavki semantičkog diferencijala (H i R procena umetničke vrednosti). Kompozicije su izlagane različitim redosledom uzimajući u obzir umetničke pravce kojima pripadaju. Redosled umetničkih pravaca je nasumično određen, ali tako da kompozicije koje pripadaju jednom pravcu ne budu prikazivane ispitanicima jedna za drugom. Na primer, najpre je izložena jedna kompozicija koja pripada apstraktnom slikarstvu, potom ona koja pripada ekpresionizmu, pa fovizmu, i tako dalje. Samim tim, vodilo se računa da se umetnički pravci ne smenjuju istim redosledom, da bi se kontrolisao potencijalni efekat redosleda izlaganja stimulusa na odgovaranje ispitanika, tako što je nakon jednog redosleda stimulusa, sledio drugi niz u kome su se umetnički pravci smenjivali drugačijim redosledom. Redosled izlaganja bio je isti za sve ispitanike. Popunjavanje upitnika je trajalo oko 30 minuta, dok je prikupljanje podataka trajalo mesec dana.

\section{Instrumenti}

Skala pozitivnog i negativnog perfekcionizma (The Positive and Negative Perfectionism Scale, PANPS; Terry-Short et al., 1995) se sastoji od 40 ajtema, od kojih se 20 odnosi na pozitivni perfekcionizam, a preostalih 20 na negativni. U pitanju je petostepena skala Likertovog tipa $(1=$ Uopšte se ne slažem, 2 =Uglavnom se ne slažem, 3 = Niti se slažem, niti se ne slažem, $4=$ Uglavnom se slažem, $5=U$ potpunosti se slažem). Skalu sačinjavaju četiri subdimenzije, a to su: Pozitivni perfekcionizam usmeren na sebe, Društveno propisan pozitivni perfekcionizam, Negativni perfekcionizam usmeren na sebe i Društveno propisan negativni perfekcionizam. Mogući skorovi na svakoj subskali se kreću od 10 do 50. Kombinovanjem skorova na prve dve subskale dobija se subskala višeg reda pod nazivom Pozitivni perfekcionizam, a preostale dve subskale čine Negativni perfekcionizam (20 ajtema). Pouzdanost interne konzistencije za Pozitivni perfekcionizam iznosi $\alpha=.82$, a za Negativni $\alpha=.89$ (Terry-Short et al., 1995). Pouzdanost cele skale u ovom istraživanju iznosi $\alpha=.86$, 
dok je za pojedinačne subskale pouzdanost sledeća: Pozitivni perfekcionizam očekivan od sebe $\alpha=$. 70, Pozitivni perfekcionizam društveno propisan $\alpha=$. 70, Negativni perfekcionizam očekivan od sebe $\alpha=.88$, Negativni perfekcionizam društveno propisan $\alpha=.84$. Ova skala je odabrana da bi se videlo da li se pozitivni i negativni perfekcionizam razikuju u pogledu predikcije umetničke vrednosti jer predstavljaju međusobno različite konstrukte.

Skala divljenja (Awe Experience Scale, AWE-S; Yaden et al., 2018) se sastoji iz 30 ajtema. Ovi ajtemi sačinjavaju šest subskala. Naime, po pet ajtema pripada svakoj subskali, a one su: Izmenjena percepcija vremena, Samoumanjivanje, Povezanost, Prostranstvo (Percepcija veličine/ogromnosti), Fizičke senzacije i Potreba za prilagođavanjem. Veći skorovi na ovim skalama ukazuju na veći subjektivni doživljaj divljenja. Skala je Likertovog tipa i to sedmostepena, pri čemu brojevi znače sledeće: $1=$ Uopšte se ne slažem, 2 = Ne slažem se, 3 = Donekle se ne slažem, $4=$ Niti se slažem niti se ne slažem, 5 = Donekle se slažem, $6=$ Slažem se, $7=U$ potpunosti se slažem. Autori testa navode da pouzdanost interne konzistencije instrumenta iznosi $\alpha=.92$ (Yaden et al., 2018), dok u ovom istraživanju ona ima vrednost $\alpha=.94$. Pouzdanost subskala iznosi: Izmenjena percepcija vremena $\alpha=.89$, Samoumanjivanje $\alpha=.94$, Povezanost $\alpha=.92$, Ogromnost $\alpha=.95$, Fizičke senzacije $\alpha=.82$, Potreba za prilagođavanjem $\alpha=.90$.

H i R nivo estetske procene operacionalizovani su skalama semantičkog diferencijala (Pejić i Milićević, 2007). Za operacionalizaciju H i R nivoa korišćeno je ukupno šest skala semantičkog diferencijala sa opozitnim pridevima. Po tri skale sa opozitnim pridevima su korišćene za oba nivoa estetske obrade, a to su: sklad - H (nesimetrično - simetrično, precizno - neprecizno, haotično - sređeno) i redundasa (ukras) - R (siromašno - bogato, skromno - raskošno, globalno-detaljno).

Skalom semantičkog diferencijala (Pejić i Milićević, 2007) takođe je ispitivana i procenjena umetnička vrednost stimulusa (umetnički vredno - umetnički bezvredno).

\section{Stimulusi}

Izabrana su dela iz devet glavnih umetničkih pravaca, a to su: renesansa, romantizam, impresionizam, ekspresionizam, postimpresionizam, fovizam, kubizam, apstraktna umetnost i nadrealizam. Za svaki umetnički pravac izabran je po jedan poznati predstavnik i tri njegova dela, kako bi kvalitet dela bio ujednačen, a to su: Večeli Ticijan, Vilijam Tarner, Pjer Ogist Renoar, Oskar Kokoška, Pol Gogen, Žorž Brak, Kazimir Maljevič i Salvador Dali. Pritom, izbegavane su njihove najpoznatije kompozicije.

Kao predstavnik renesanse odabran je Večeli Ticijan. Potom su izabrana naredna njegova dela: "Man with a Glove", "Christ Carrying the Cross" i "Mary with the Child and Saints".

Za romantizam je izabran Vilijan Tarner, a kompozicije su: "Venice with the Salute", "The Slave Ship" i "Calais Pier, with French Poissards Preparing for Sea, an English Packeet Arriving”.

Kada je u pitanju impresionizam, odabrana dela su: "A Walk in the Woods 
(Madame Lecoeur and Her Children)", "The Seine at Asnieres (The Skiff)" i "La Grenouillere", Pjer Ogista Renoara.

Što se tiče ekspresionizma, tu je odabran Oskar Kokoška. Dela koja su izabrana su: "The Elbe Near Dresden", "Bride of the Wind" i "Anschluß - Alice in Wonderland".

Postimpresionizam je predstavljen delima Pola Gogena. Kao tri potrebne kompozicije su odabrana sledeća dela: "Dogs running through a field", "Around the huts" $\mathrm{i}$ "The Vision after the Sermon (Jacob wrestling with the Angel)".

Naredni pravac je fovizam. Kao njegov predstavnik odabran je Žorž Brak, sa sledećim delima: "Still Life with Jugs and Pipe", "Ship at Le Havre" i "Port of La Ciotat".

Za kubizam su takođe izabrana dela Žorža Braka i to: "Napkin, knife and pears", "Fishing boats" i "Café Bar".

Za predstavnika apstraktne umetnosti je odabran Kazimir Maljevič i kompozicije: "Black Square and Red Square", "Suprematist composition" i "Supermatism" čiji je originalni naslov "Супрематизм. Живописные объемы в движении”.

I na kraju, nadrealizam. Za njega je odabran njegov najpoznatiji predstavnik, Salvador Dali. Korišćene kompozicije su: "Study for "Honey is Sweeter than Blood", "The Disintegration of the Persistence of Memory" $i$ "The Metamorphosis of Narcissus".

Različiti umetnički pravci su uzeti kao kontrola, da se ne bi mešao efekat pravca sa procenama vrednosti. Dakle, ispitanici su procenjivali H i R dimenzije za različite umetničke pravce, a u ovom istraživanju je korišćen ukupan skor na $\mathrm{H}$ i R dimenzijama, odnosno, nisu korišćeni skorovi na $\mathrm{H}$ i R dimenzijama za svaki umetnički pravac zasebno.

\section{Rezultati}

Sudeći po ranije pomenutoj teoriji, visokoj korelaciji između D nivoa i Umetničke vrednosti $(r=.94, p=.00)$, ali i dobijenoj vrednosti $\beta(\beta=1.05, p=.00) \mathrm{u}$ ovom istraživanju, u postupku hijerarhijske regresione analize, gde je D nivo uzet kao prediktor Umetničke vrednosti, D nivo neće biti korišćen kao prediktor u ovom istraživanju jer objašnjava preveliki deo varijanse i usled toga ostali prediktori ne mogu doći do izražaja. Naime, postoji veliko preklapanje između D nivoa i Umetničke vrednosti, jer i sam D nivo uključuje procenu umetničke vrednosti.

U narednoj tabeli su prikazane deskriptivno statističke mere.

Tabela 1

Deskriptivna statistika varijabli istraživanja

\begin{tabular}{lccrrrr}
\hline & $A S$ & \multicolumn{1}{c}{ SD } & \multicolumn{1}{c}{ Min } & Max & \multicolumn{1}{c}{ Sk } & \multicolumn{1}{c}{ Ku } \\
\hline Umetnička vrednost & 1.51 & 0.83 & -0.89 & 2.81 & -0.51 & 0.28 \\
H & 0.73 & 0.65 & -0.49 & 2.65 & 0.70 & 0.64 \\
R & 0.70 & 0.63 & -0.44 & 2.65 & 0.78 & 0.50
\end{tabular}




\begin{tabular}{|c|c|c|c|c|c|c|}
\hline $\begin{array}{l}\text { Pozitivni perfekcionizam } \\
\text { očekivan od sebe }\end{array}$ & 4.02 & 0.47 & 2.70 & 4.90 & -0.51 & 0.16 \\
\hline $\begin{array}{l}\text { Pozitivni perfekcionizam } \\
\text { društveno propisan }\end{array}$ & 3.62 & 0.53 & 2.30 & 4.90 & -0.04 & 0.14 \\
\hline $\begin{array}{l}\text { Negativni perfekcionizam } \\
\text { očekivan od sebe }\end{array}$ & 2.92 & 0.88 & 1.50 & 5.00 & 0.50 & -0.12 \\
\hline $\begin{array}{l}\text { Negativni perfekcionizam } \\
\text { društveno propisan }\end{array}$ & 2.77 & 0.81 & 1.40 & 5.00 & 0.66 & 0.29 \\
\hline $\begin{array}{l}\text { Izmenjena percepcija } \\
\text { vremena }\end{array}$ & 4.10 & 1.56 & 1.00 & 7.00 & -0.35 & -0.66 \\
\hline Samoumanjivanje & 3.47 & 1.87 & 1.00 & 7.00 & 0.34 & -1.04 \\
\hline Povezanost & 4.03 & 1.75 & 1.00 & 7.00 & -0.06 & -1.02 \\
\hline Ogromnost-veličina & 4.52 & 1.85 & 1.00 & 7.00 & -0.51 & -0.83 \\
\hline Fizičke senzacije & 4.00 & 1.56 & 1.00 & 7.00 & -0.13 & -0.60 \\
\hline $\begin{array}{l}\text { Potreba za } \\
\text { prilagođavanjem }\end{array}$ & 3.91 & 1.66 & 1.00 & 7.00 & 0.10 & -0.72 \\
\hline
\end{tabular}

Napomena. $A S=$ aritmetička sredina; $S D=$ standardna devijacija; $\max =$ maksimalna vrednost; $\min =$ minimalna vrednost; $S k=$ vrednost skjunesa; $K u=$ vrednost kurtozisa.

Aritmetička sredina umetničke vrednosti je 1.51, standardna devijacija iznosi 0.83, dok su minimum i maksimum -0.89, odnosno 2.81. Srednja vrednost H nivoa iznosi $0.73(S D=0.65)$, a $\mathrm{R}$ nivoa $.70(S D=.63)$. Aritmetička sredina na subskalama perfekcionizma ide od 2.77, kolika je na subskali Negativni perfekcionizam društveno propisan, do 4.02, na subskali Pozitivni perfekcionizam očekivan od sebe. Kada su u pitanju subskale divljenja, aritmetičke sredine se kreću od 3.47, na subskali Samoumanjivanja, do 4.52, na subskali Ogromnosti.

Nema nedostajućih odgovora.

Sledi prikaz korelacija između korišćenih varijabli.

Tabela 2

Korelacija između varijabli

\begin{tabular}{|c|c|c|c|c|c|c|c|c|c|c|c|c|c|}
\hline & 1 & 2 & 3 & 4 & 5 & 6 & 7 & 8 & 9 & 10 & 11 & 12 & 13 \\
\hline $\begin{array}{l}\text { 1) Umetnička } \\
\text { vrednost }\end{array}$ & - & & & & & & & & & & & & \\
\hline 2) $\mathrm{H}$ & $.45 * *$ & - & & & & & & & & & & & \\
\hline 3) $R$ & $.52 * *$ & $.68^{* *}$ & - & & & & & & & & & & \\
\hline 4) Pozitivni & & & & & & & & & & & & & \\
\hline $\begin{array}{l}\text { perfekcionizam } \\
\text { očekivan od sebe }\end{array}$ & .16 & $.25^{*}$ & $.21^{*}$ & - & & & & & & & & & \\
\hline 5) Pozitivni & & & & & & & & & & & & & \\
\hline $\begin{array}{l}\text { perfekcionizam } \\
\text { društveno propisan }\end{array}$ & .13 & .19 & .17 & $.54 * *$ & - & & & & & & & & \\
\hline 6) Negativni & & & & & & & & & & & & & \\
\hline $\begin{array}{l}\text { perfekcionizam } \\
\text { očekivan od sebe }\end{array}$ & -.02 & -.16 & -.06 & -.11 & .09 & - & & & & & & & \\
\hline
\end{tabular}




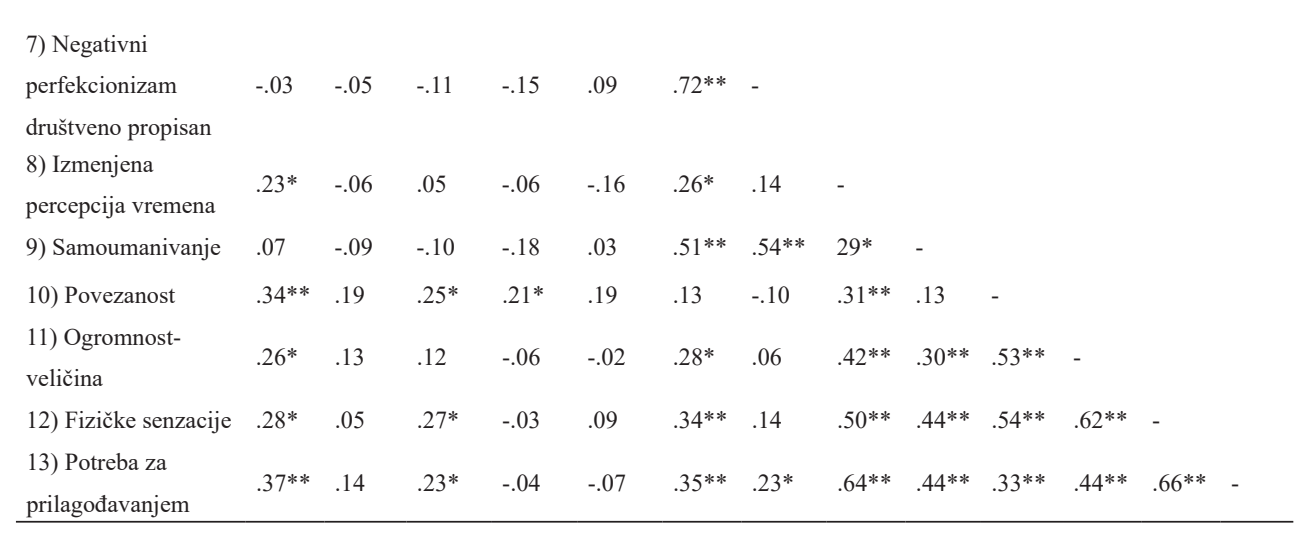

Napomena. $* p<.05, * * p<.01$.

Rezulati iz tabele ukazuju da postoji statistički značajna povezanost između Umetničke vrednosti i H, R, Izmenjene percepcije vremena, Povezanosti, Ogromnosti/ veličine, Fizičkih senzacija i Potrebe za prilagođavanjem. Najveća korelacija je između R nivoa i Umetničke vrednosti $(r=.52, p<.01)$, a najmanja između Izmenjene percepcije vremena i Umetničke vrednosti $(r=.23, p<.05)$. Sve korelacije su pozitivne. Moguće je postojanje multikolinearnosti. Multikolinearnost govori da postoji visoka korelacija između prediktora, što znači da oni dele relativno veći deo varijanse. Ona dalje podrazumeva da postoji mogućnost da kriterijum predviđa upravo taj zajednički deo varijanse prediktora, a ne svaki od njih zasebno. Naime, smatra se da se u postojanje multikolinearnosti može sumnjati onda kada je korelacija između prediktora po visini $>.7$ i statistički značajna. Iz prethodne tabele može se videti da je korelacija između dve vrste negativnog perfekcionizma viša od .7 $(r=.72)$, usled čega se sumnja na postojanje multikolinearnosti između ovih prediktora. Međutim, pošto nijedna od ove dve vrste perfekcionizma nije u statistički značajnoj korelaciji sa kriterijumom, niti se kasnije izdvaja kao statistički značajan prediktor kriterijuma, dalje provere multikolinearnosti nisu sprovođene, kao ni postupci za njeno otklanjanje.

Podaci su obrađivani hijerarhijskom regresionom analizom. Prediktori su modusi estetske obrade ( $\mathrm{H}$ - harmonija i $\mathrm{R}$ - redundansa), perfekcionizam, tačnije njegove subskale (Pozitivni perfekcionizam očekivan od sebe, Društveno propisan pozitivni perfekcionizam, Negativni perfekcionizam očekivan od sebe, Društveno propisan negativni perfekcionizam) i subskale divljenja (Izmenjena percepcija vremena, Samoumanjivanje, Povezanost, Ogromnost/veličina, Fizičke senzacije i Potreba za prilagođavanjem). U prvom koraku su ubačeni modusi estetske obrade, $\mathrm{u}$ narednom su dodate subskale perfekcionizma i u poslednjem subskale divljenja. Kriterijum predstavlja umetnička vrednost. Kako nisu pronađeni slični radovi, odlučeno je da prediktori budu ubačeni pomenutim redosledom, usled toga što su dimenzije H i R direkno vezane za procenu umetničkih dela (Ognjenović, 2003), nakon njih su dodate subskale perfekcionizma i divljenja. Perfekcionizam je dodat u ranijem koraku u odnosu na divljenje jer on pripada domenu ličnosti (Terry-Short et al., 1995), dok divljenje predstavlja emociju (Ketlner \& Haidt, 2003). 


\section{Tabela 3}

Harmonija, Redundantnost, perfekcionizam i divljenje kao prediktori umetničke vrednosti

\begin{tabular}{|c|c|c|c|c|c|c|c|c|c|}
\hline Prediktori & $\beta$ & $t$ & $p$ & $R$ & Adj. $R^{2}$ & $\Delta F$ & $p$ & $F$ & $p$ \\
\hline & & & & .54 & .26 & 11.47 & .00 & 11.47 & .00 \\
\hline Harmonija & .18 & 1.21 & .23 & & & $(2,57)$ & & $(2,57)$ & \\
\hline \multirow[t]{2}{*}{ Redundantnost } & .39 & 2.59 & .01 & & & & & & \\
\hline & & & & .54 & .21 & 11.47 & .10 & 3.58 & .00 \\
\hline Harmonija & .18 & 1.11 & .27 & & & $(4,53)$ & & $(6,53)$ & \\
\hline Redundantnost & .39 & 2.40 & .02 & & & & & & \\
\hline $\begin{array}{l}\text { Pozitivni perfekcionizam } \\
\text { očekivan od sebe }\end{array}$ & .02 & 0.17 & .86 & & & & & & \\
\hline $\begin{array}{l}\text { Pozitivni perfekcionizam } \\
\text { društveno propisan }\end{array}$ & .01 & 0.06 & .95 & & & & & & \\
\hline $\begin{array}{l}\text { Negativni perfekcionizam } \\
\text { očekivan od sebe }\end{array}$ & .02 & 0.14 & .89 & & & & & & \\
\hline \multirow[t]{2}{*}{$\begin{array}{l}\text { Negativni perfekcionizam } \\
\text { društveno propisan }\end{array}$} & .01 & 0.04 & .97 & & & & & & \\
\hline & & & & .64 & .25 & 0.12 & .19 & 2.66 & .01 \\
\hline Harmonija & .09 & 0.51 & .61 & & & $(6,47)$ & & $(12,47)$ & \\
\hline Redundantnost & .37 & 2.18 & .03 & & & & & & \\
\hline $\begin{array}{l}\text { Pozitivni perfekcionizam } \\
\text { očekivan od sebe }\end{array}$ & -.00 & -0.03 & .97 & & & & & & \\
\hline $\begin{array}{l}\text { Pozitivni perfekcionizam } \\
\text { društveno propisan }\end{array}$ & .07 & 0.49 & .63 & & & & & & \\
\hline $\begin{array}{l}\text { Negativni perfekcionizam } \\
\text { očekivan od sebe }\end{array}$ & -.18 & -0.97 & .33 & & & & & & \\
\hline $\begin{array}{l}\text { Negativni perfekcionizam } \\
\text { društveno propisan }\end{array}$ & .08 & 0.41 & .69 & & & & & & \\
\hline $\begin{array}{l}\text { Izmenjena percepcija } \\
\text { vremena }\end{array}$ & .07 & 0.42 & .68 & & & & & & \\
\hline Samoumanjivanje & .04 & 0.29 & .77 & & & & & & \\
\hline Povezanost & .17 & 1.11 & .27 & & & & & & \\
\hline Ogromnost & .10 & 0.65 & .52 & & & & & & \\
\hline Fizičke senzacije & -.17 & -0.86 & .39 & & & & & & \\
\hline $\begin{array}{l}\text { Potreba za } \\
\text { prilagođavanjem }\end{array}$ & .28 & 1.50 & .14 & & & & & & \\
\hline
\end{tabular}

Napomena. $\beta=$ standardizovani regresioni koeficijent; $t=\mathrm{t}$ statistik; $R=$ koeficijent multiple korelacije; $A d j . R^{2}=$ prilagođeni koeficijent determinacije; $F=$ F statistik; $\Delta F$ $=$ promena $\mathrm{F}$ statistika. 
Sva tri modela su statistički značajna, ali subskale perefekcionizma (Pozitivni perfekcionizan očekivan od sebe, Društveno propisan pozitivni perfekcionizam, Negativni perfekcionizam očekivan od sebe, Društveno propisan negativni perfekcionizam) i subskale divljenja (Izmenjena percepcija vremena, Samoumanjivanje, Povezanost, Ogromnost/veličina, Fizičke senzacije, Potreba za prilagođavanjem) ne daju statistički značajan doprinos predikciji. Koeficijent multiple determinacije iznosi .26, što znači da dva modusa estetske obrade uzeta zajedno objašnjavaju $26 \%$ ukupne varijanse umetničke vrednosti. Na osnovu R koeficijenta se vidi da je korelacija između prediktora, dakle H i R, i kriterijuma, Umetničke vrednosti, srednjeg intenziteta.

Kada su u pitanju pojedinačni doprinosi prediktora, statistički značajan prediktor je samo R, redundantnost, čija je korelacija sa Umetničkom vrednošću pozitivna $(\beta=.39, t=2.59, p=.01)$.

U nastavku su prikazane vrednosti regresije koje su dobijene kada su varijable ubacivane suprotnim redosledom. Naime, u prvom koraku su uključene subskale divljenja, u narednom subskale perfekcionizma, i na kraju i modusi estetske obrade. S obzirom da H i R objašnjavaju najveći deo varijanse, a kako se kao jedini značajan prediktor izdvojila dimezija $\mathrm{R}$, i kako nisu pronađena istraživanja koja su se ranije bavila ovim varijablama, sproveden je još jedan postupak regresione analize kako bi se videlo da li se možda neki od preostalih prediktora izdvajaju kao značajni kada se promeni redosled njihovog ubacivanja u hijerarhijsku regresionu analizu. Takođe, još jedan razlog sprovođenja regresione analize sa obrnutim redosledom prediktora je i provera da li možda H i R objašnjavaju deo varijanse koji bi inače mogli da objasne i ostali prediktori kada bi bili ubačeni u ranijem koraku u odnosu na H i R.

\section{Tabela 4}

Divljenje, perfekcionizam, Harmonija i Redundantnost kao prediktori umetničke vrednosti

\begin{tabular}{|c|c|c|c|c|c|c|c|c|c|}
\hline Prediktori & $\beta$ & $t$ & $p$ & $R$ & Adj. $R^{2}$ & $\Delta F$ & $p$ & $F$ & $p$ \\
\hline & & & & .46 & .12 & 2.34 & .04 & 2.34 & .04 \\
\hline $\begin{array}{l}\text { Izmenjena percepcija } \\
\text { vremena }\end{array}$ & -.06 & -0.36 & .72 & & & $(6,53)$ & & $(6,53)$ & \\
\hline Samoumanjivanje & -.10 & -0.70 & .49 & & & & & & \\
\hline Povezanost & .26 & 1.67 & .10 & & & & & & \\
\hline Ogromnost & .06 & 0.36 & .72 & & & & & & \\
\hline Fizičke senzacije & -.09 & -0.46 & .65 & & & & & & \\
\hline \multirow[t]{2}{*}{$\begin{array}{l}\text { Potreba za } \\
\text { prilagođavanjem }\end{array}$} & .40 & 2.13 & .04 & & & & & & \\
\hline & & & & .50 & .10 & 0.72 & .58 & 1.67 & .12 \\
\hline $\begin{array}{l}\text { Izmenjena percepcija } \\
\text { vremena }\end{array}$ & -.02 & -0.13 & .90 & & & $(4,49)$ & & $(10,49)$ & \\
\hline Samoumanjivanje & -.05 & -0.32 & .75 & & & & & & \\
\hline Povezanost & .22 & 1.32 & .19 & & & & & & \\
\hline Ogromnost & .11 & 0.65 & .52 & & & & & & \\
\hline Fizičke senzacije & -.09 & -0.45 & .66 & & & & & & \\
\hline
\end{tabular}




\begin{tabular}{|c|c|c|c|c|c|c|c|c|}
\hline $\begin{array}{l}\text { Potreba za } \\
\text { prilagođavanjem }\end{array}$ & .43 & 2.19 & .03 & & & & & \\
\hline $\begin{array}{l}\text { Pozitivni } \\
\text { perfekcionizam } \\
\text { očekivan od sebe }\end{array}$ & .05 & 0.32 & .75 & & & & & \\
\hline $\begin{array}{l}\text { Pozitivni } \\
\text { perfekcionizam } \\
\text { društveno propisan }\end{array}$ & .11 & 0.68 & .50 & & & & & \\
\hline $\begin{array}{l}\text { Negativni } \\
\text { perfekcionizam } \\
\text { očekivan od sebe }\end{array}$ & -.25 & -1.31 & .19 & & & & & \\
\hline \multirow[t]{2}{*}{$\begin{array}{l}\text { Negativni } \\
\text { perfekcionizam } \\
\text { društveno propisan }\end{array}$} & .11 & 0.57 & .57 & & & & & \\
\hline & & & .64 & .25 & 5.95 & .00 & 2.66 & .01 \\
\hline $\begin{array}{l}\text { Izmenjena percepcija } \\
\text { vremena }\end{array}$ & .07 & 0.42 & .68 & & $(2,47)$ & & $(12,47)$ & \\
\hline Samoumanjivanje & .04 & 0.29 & .77 & & & & & \\
\hline Povezanost & .17 & 1.11 & .27 & & & & & \\
\hline Ogromnost & .10 & 0.65 & .52 & & & & & \\
\hline Fizičke senzacije & -.17 & -0.86 & .39 & & & & & \\
\hline $\begin{array}{l}\text { Potreba za } \\
\text { prilagođavanjem }\end{array}$ & .28 & 1.50 & .14 & & & & & \\
\hline $\begin{array}{l}\text { Pozitivni } \\
\text { perfekcionizam } \\
\text { očekivan od sebe }\end{array}$ & -.00 & -0.03 & .97 & & & & & \\
\hline $\begin{array}{l}\text { Pozitivni } \\
\text { perfekcionizam } \\
\text { društveno propisan }\end{array}$ & .07 & 0.49 & .63 & & & & & \\
\hline $\begin{array}{l}\text { Negativni } \\
\text { perfekcionizam } \\
\text { očekivan od sebe }\end{array}$ & -.18 & -0.97 & .33 & & & & & \\
\hline $\begin{array}{l}\text { Negativni } \\
\text { perfekcionizam } \\
\text { društveno propisan }\end{array}$ & .08 & 0.41 & .69 & & & & & \\
\hline Harmonija & .09 & 0.51 & .61 & & & & & \\
\hline Redundantnost & .37 & 2.18 & .03 & & & & & \\
\hline
\end{tabular}

Napomena. $\beta=$ standardizovani regresioni koeficijent; $t=\mathrm{t}$ statistik; $R=$ koeficijent multiple korelacije; $A d j . R^{2}=$ prilagođeni koeficijent determinacije; $F=$ F statistik; $\Delta F$ $=$ promena $\mathrm{F}$ statistika.

Iz tabele vidimo da je prvi model, sačinjen od subskala divljenja, statistički značajan i da objašnjava 12\% ukupne varijanse. Koeficijent multiple korelacije pokazuje da je korelacija kriterijuma i prediktora srednjeg intenziteta. Kada se dodaju subskale perfekcionizma model prestaje da bude značajan, ali kada se dodaju i modusi estetske obrade model ponovo postaje značajan. Poslednji model, sačinjen od perfekcionizma, divljenja i H i R objašnjava 25\% ukupne varijanse. 
R se opet pokazao kao značajan prediktor i on ima pozitivnu korelaciju sa Umetničkom vrednošću $(\beta=.37, t=2.18, p=.03)$.

Subskala divljenja pod nazivom Potreba za prilagođavanjem je u prva dva modela statistički značajna, a u trećem modelu značajnost prestaje da postoji. Kako ova subskala prestaje da bude značajna kada se u regresioni model dodaju modusi estetske preferencije, od kojih je jedino R statistički značajan, može se pretpostaviti da je $\mathrm{R}$ potencijalni medijator $\mathrm{u}$ odnosu između Potrebe za prilagođavanjem i procenjene umetničke vrednosti. Ova mogućnost je proverena medijacionom analizom putem makroa PROCES. Rezultati su prikazani u narednoj tabeli. Intervali poverenja konstruisani su boostrap metodom (broj bootstrap uzoraka - 5000).

\section{Tabela 5}

Rezultati medijacione analize

\begin{tabular}{lllllllll}
\hline$R$ & $R^{2}$ & $p$ & $a$ & $p$ & $b$ & $c$ & $L L C I$ & ULCI \\
\hline .56 & .31 & .00 & .17 & .01 & .14 & .03 & -.02 & .09 \\
\hline
\end{tabular}

Napomena. a - totalni efekat; b - direktni efekat; c - indirektni efekat; LLCI - donja granica intervala poverenja; ULCI - gornja granica intervala poverenja.

Kako donja granica ima negativan, a gornja pozitivan predznak, što znači da se između granica nalazi nula, može se zaključiti da indirektan efekat nije značajan i da medijacija ne postoji tj. da R nije medijator između Potrebe za prilagođavanjem i procenjene umetničke vrednosti.

\section{Diskusija}

Cilj istraživanja je bio ispitati da li je na osnovu modusa estetske obrade (H i $\mathrm{R}$ ), subskala perfekcionizma i divljenja moguće predvideti procenu umetničke vrednosti kompozicija. Sva tri modela su se pokazala kao statisički značajna, kada su najpre dodati estetski modusi, a potom i subskale divljenja i perfekcionizma, ali poslednje dve varijable ne daju statistički značajan doprinos predikciji. Kada su prediktori uključivani suprotnim redosledom, prvi model sačinjen od subskala divljenja se pokazao kao značajan, dodavanjem subskala perfekcionizma statistička značajnost prestaje da postoji, a ponovo se pojavljuje dodavanjem estetskih modusa. Analiza doprinosa pojedinačnih prediktora pokazuje da je R statistički značajan prediktor Umetničke vrednosti. Viši nivoi Redundantnosti predviđaju veću Umetničku vrednost. Ovakvi rezultati su u skladu sa nalazima Spomenke Graovac (1994) koja je među svojim ispitanicima utvrdila dominaciju R nivoa estetske obrade. Ognjenović i Morača (1994) takođe navode da su kod njihovih ispitanika, studenata, dominantni estetski sudovi karatkeristični za nivoe obrade koji su niži, iako ispitanici nemaju vremensko ograničenje pri odabiru stimulusa. Dakle, oni su dominatno birali stimuluse koji pripadaju R nivou. Ognjenović i Morača (1994), ali i Milićević (2019), smatraju da bi uzrok ovakih rezultata mogao biti pad kvaliteta obrazovanja. Miliće- 
vić (2019) napominje kao uzrok i pad kulturnih, ali i socijalnih vrednosti, i sveprisutnu dominaciju kiča, kako u medijima tako i u društvu.

Kao što je rečeno, postoji pozitivna korelacija između Umetničke vrednosti i Izmenjene percepcije vremena, Povezanosti, Percepcije ogromnosti/veličine, Fizičkih senzacija i Potrebe za prilagođavanjem. Pozitivna povezanost Umetničke vrednosti i Izmenjene percepcije vremena ukazuje na to da posmatranjem dela koje ocenimo kao umetnički vrednije stičemo utisak izmenjenosti vremena, poput utiska da vreme prolazi drugačije, sporije ili da čak privremeno staje. Pomenuti rezultat je u skladu sa nalazima Ruda i saradnika (Rudd et al., 2012). Rezultati njihovog istraživanja ukazuju da osobe u situaciji divljenja percipiraju veću raspoloživost vremena (Rudd et al., 2012). Poznat je i flow doživljaj u kome se menja subjektivna percepcija vremena (Csikszentmihalyi, 1997). Kada je u pitanju Povezanost, rezultati pokazuju da je veća šansa da imamo osećaj povezanosti ili jedinstva i zajedništva sa delom, ukoliko je ono procenjeno kao vrednije. To je u skladu sa nalazima Shiote i saradnika (Shiota et al., 2007) koji govore o tome da se u iskustvima divljenja javlja osećaj povezanosti sa okolinom. Akomodacija odnosno Prilagođavanje podrazumeva promenu mentalne šeme da bi se obradilo doživljeno iskustvo (Yaden et al., 2018). Iskustvo divljenja je negativno povezano sa kognitivnim zatvaranjem (Shiota et al., 2007), a rezultati sprovedenog istraživanja ukazuju na pozitivnu korelaciju između divljenja i procene umetničke vrednosti. Povezanost sa Percepcijom ogromnosti ukazuje da imamo osećaj da se nalazimo u prisustvu nečeg grandioznog, nečeg što je veće od nas. Ovaj rezultat je u skladu sa navodima Konečnog (2005) koji estetsko divljenje smatra odgovorom na uzvišeni sadržaj, koji je pak kulturološki uslovljen, i podrazumeva lepotu, nešto što je retko ili veliko, u fizičkom smislu. Takođe je u saglasnosti sa nalazima Šiote i saradnika (Shiota et al., 2007) koji dolaze do istog zaključka, a to je da se osećamo umanjeno prilikom iskustva divljenja. Konečni (2005) takođe navodi da je divljenje praćeno i drhtavicom, a da je vrlo čest estetski odgovor i uzbuđenje, što je takođe u skladu sa nalazima ovog istraživanja. Pozitivna korelacija sa Fizičkim senzacijama ukazuje na mogućnost fizioloških promena u kontaktu sa delom koje je procenjeno kao vredno. Ovaj nalaz povrđuju i rezultati Algoe i Haita (Algoe i Haidt, 2009), da se prilikom divljenja može javiti osećaj naježenosti. Samim tim, moguće su senzacije poput širenja zenica, a javlja se i mogućnost da nam pojava izmami uzdah, ali i da reagujemo blagim otvaranjem ustiju i podizanjem obrve (Shiota et al, 2003).

Rezultati regresione analize koja je sprovedena uključivanjem varijabli obrnutim redosledom ( $\mathrm{u}$ odnosu na prvu analizu), u kojoj su najpre dodate subskale divljenja, potom subskale perfekcionizama, i na kraju i modusi estetske obrade, $\mathrm{H} \mathrm{i}$ $\mathrm{R}$, pokazali su da je model sačinjen od subskla divljenja statistički značajan, i da je subskala pod nazivom Potreba za prilagođavanjem značajan prediktor, kada su samostalno ubačene subskale divljenja, ali i kada su dodate subskale perfekcionizma. Međutim, značajnost prestaje da postoji sa dodavanjem estetskih modusa, što može ukazivati na potencijalno postojanje potpune medijacije. Međutim, rezultati medijacione analize ukazuju na to da $\mathrm{R}$ nivo nije medijator između Potrebe za prilagođavanjem i umetničke vrednosti. Perfekcionizam se nije pokazao kao značajan prediktor, 
što bi moglo da znači da je perfekcionizam bitan za preferencije (Basak, 2012), ali ne i za procenu umetničke vrednosti.

\section{Zaključak}

Cilj istraživanja je bio ispitati da li je na osnosu H i R tj. modusa estetske obrade, perfekcionizma i divljenja, moguće predvideti procenu umetničke vrednosti dela. Model sačinjen od H i R je statistički značajan, a subskale perfekcionizma i divljenja ne doprinose značajno predikciji. Kada je u pitanju obrnuta regresija, model sačinjen od subskala divljenja je značajan, potom značajnost prestaje dodavanjem subskala perfekcionizma i ponovo počinje da postoji dodatkom H i R. Rezultati pokazuju da je R odnosno redundantnost statistički značaj prediktor Umetničke vrednosti. Značaj ovog istraživanja može se odnositi na ukazivanje o povezanosti između divljenja i percepcije Umetničke vrednosti. Da bi se bolje rasvetlio ovaj odnos potrebno je nastaviti sa ovakvim i sličnim istraživanjima, a u nekim narednim kao kriterijum bi mogla biti korišćena i preferencija umetničkih dela u domenu različitih pravaca. $\mathrm{S}$ obzirom na značajnu povezanost procene umetničke vrednosti i fizičkih senzacija, u nekom narednom istraživanju bilo bi korisno sprovesti merenje istih, putem, na primer, aparata za merenje PGR-a tj. psihogalvanske reakcije.

\section{Literatura}

Algoe, S. B., \& Haidt, J. (2009). Witnessing excellence in action: the 'other-praising' emotions of elevation, gratitude, and admiration. The Journal of Positive Psychology, 4(2), 105-127. https://doi.org/10.1080/17439760802650519

Basak, R. (2012). Perfectionist attitudes of artistically talented students in the art classroom. Procedia - Social and Behavioral Sciences, 46, 5010-5014. http://dx.doi. org/10.1016/j.sbspro.2012.06.377

Csikszentmihalyi, M. (1997). Flow and the psychology of discovery and invention. Harper Perennial.

Graziosi, M., \& Yaden, D. (2019). Interpersonal awe: Exploring the social domain of awe elicitors. The Journal of Positive Psychology. Advance online publication. https:// doi.org/10.1080/17439760.2019.1689422

Graovac, S. (1994). Doslednost vizuelne i muzičke estetske preferencije. Psihologija,27 (3-4), 271-282.

Keltner D., \& Haidt J. (2003). Approaching awe, a moral, spiritual and aesthetic emotion. Cognition and Emotion, 17(2), 297-314. https://doi.org/10.1080/02699930302297

Konečni, J. V. (2005). The Aesthetic Trinity: Awe, Being Moved, Thrills. Bulletin of Psychology and the Arts. 5(2), 22-47.

Limburg, K., Watson, J. H., Hagger, S.M., \& Egan, J. S. (2017) The Relationship Between Perfectionism and Psychopathology: A meta-analysis. Journal of Clinical Psychology, 73 (10), 1301-1326. https://doi.org/10.1002/jclp.22435 
Milićević, N. (2019). Empirijska istraživanja estetskog doživljaja. Filozofski fakultet.

Ognjenović, P i Morača J. (1994). Pitanje ukusa ili de gustibus disputandum. Psihologija, 27 (3-4), 249-264.

Ognjenović, P. (2003). Psihološka teorija umetnosti. Getembergova Galaksija.

Pejić, B. i Milićević, N. (2007). Provera skale procene estetskog doživljaja [Izlaganje rada]. XIII Empirijska istraživanja u psihologiji. Knjiga rezimea (pp.25-26), Filozofski fakultet, Beograd. http://empirijskaistrazivanja.org/wp-content/uploads/2016/06/ Knjiga-Rezimea-EIP-2007.pdf

Piff, P. K., Dietze, P., Feinberg, M., Stancato, D. M., \& Keltner, D. (2015). Awe, the small self, and prosocial behavior. Journal of Personality and Social Psychology, 108(6), 883-889. https://doi.apa.org/doi/10.1037/pspi0000018

Rudd, M., Vohs, K. D., \& Aaker, J. (2012). Awe expands people's perception of time, alters decision making, and enhances well-being. Psychological Science, 23(10), 1130-1136. https://doi.org/10.1177\%2F0956797612438731

Shiota, M. N., Campos, B. \& Keltner, D. (2003). The faces of positive emotion: Prototype displays of awe, amusement, and pride. Annals of the New York Academy of Sciences, 1000(1), 296-299. https://doi.org/10.1196/annals.1280.029

Shiota, M. N., Keltner, D., \& Mossman, A. (2007). The nature of awe: Elicitors, appraisals, and effects on self-concept. Cognition and Emotion, 21(5), 944-963. https:// psycnet.apa.org/doi/10.1080/02699930600923668

Skiner, B. F. (1969). Contingencies of Reinforcement: A Theoretical Analysis. AppletonCentury-Crofts.

Slade, D. P. \& Owens, R. G. (1998). A Dual Process Model of Perfectionism Based on Reinforcement Theory. Behavior modification, 22(3), 372-390. https://doi. org/10.1177/01454455980223010

Stellar, J. E., Gordon, A., Anderson, C. L., Piff, P. K., McNeil, G. D. \& Keltner, D. (2018). Awe and humility. Journal of Personality and Social Psychology, 114(2), 258-269. https://psycnet.apa.org/doi/10.1037/pspi0000109

Terry-Short, L.A., Owens, G., Slade, D. P. \& Dewey M. E., (1995) PNPS; Positive and Negative Perfectionism Scale. Personality and Individual Differences, 18(5), 663668. https://doi.org/10.1016/0191-8869(94)00192-U

Yaden, D., Kaufman S. B., Hyde. E., Chirico, A., Gaggioli, A., Zhang, J. W. \& Keltner, D. (2018). The development of the Awe Experience Scale (AWE-S): A multifactorial measure for a complex emotion. The Journal of Positive Psychology, 14(4), 474-488. https://psycnet.apa.org/doi/10.1080/17439760.2018.1484940 
Miljana Nikolić ${ }^{3}$

Departman of Psychology

Faculty of Philosophy

University of Niš

Niš, Serbia

\title{
PERFECTIONISM, AWE AND MODES OF AESTHETIC PROCESSING AS PREDICTORS OF PERCEIVED ARTISTIC VALUE
}

\begin{abstract}
The aim of the research was to examine whether the perceived artistic value of the paintings can be predicted by perfectionism and awe, as well as with the modes of aesthetic processing ( $\mathrm{H}$ - harmony and $\mathrm{R}$ - redundancy). The convenience sample was used and it consisted of 92 respondents $\left(N_{\text {male }}=10, N_{\text {female }}=82\right)$, with average age of 24.65 years $(S D=6.89)$. Following instruments were used: Scale of Positive and Negative Perfectionism, Awe Experience Scale and semantic differential scales used to assess harmony, redundancy and distance, as well as the perceived artistic value. Stimuli were paintings from nine artistic movements: Renaissance, Romanticism, Impressionism, Expressionism, Post-impressionism, Fauvism, Cubism, Abstract Art and Surrealism. For each of these movements three paintings of one most prominent representative were chosen (omitting the most famous pieces) in order for the quality of artwork to be uniform. Hierarchical linear regression was used for data analysis. Predictors in the first step were modes of aesthetic processing ( $\mathrm{H}$ and $\mathrm{R}$ ), perfectionism in the second step, and subscales of awe were added in the third step. The criterion is artistic value. The model composed of $\mathrm{H}$ and $\mathrm{R}$ explains $26 \%$ of the total variance of artistic value ( $p$ $<.01)$. The suscales of perfectionism and awe do not make a significant contribution to prediction. A statistically significant single predictor is $\mathrm{R}$, redundancy $(\beta=.39, t=$ $2.59, p=.01)$. The potential existence of mediation was also examined; however, the results of the analysis indicate that there is no statistically significant mediator effect.
\end{abstract}

Keywords: perfectionism, awe, modes of aesthetic processing, Harmony, Redundancy

Primljeno: 30.06.2020.

Primljena korekcija: 14.05.2021.

Prihvaćeno za objavljivanje:12.07.2021.

\footnotetext{
${ }^{3}$ miljananikolic977@gmail.com

Please cite as: Nikolić, M. (2021). Modusi estetske obrade, perfekcionizam i divljenje kao prediktori umetničke vrednosti [Perfectionism, awe and modes of aesthetic processing as predictors of perceived artistic value]. Godišnjak za psihologiju, 18, 107-122. https://doi.org/ 10.46630/gpsi.18.2021.07
} 